\title{
New insights into the genesis of peridotite-pyroxenite layers: Western Gneiss Region, Norway
}

\author{
Anja Rosenthal ${ }^{1}$, Gregory M. Yaxley ${ }^{1}$, David H. Green ${ }^{1}$, Heidi E. Hoefer ${ }^{2}$, Joerg Hermann ${ }^{1}$ \\ and Carl S. Spandler ${ }^{3}$ \\ ${ }^{1}$ Research School of Earth Sciences, The Australian National University, Canberra ACT 0200, Australia \\ ${ }^{2}$ Institute of Geosciences, Johann Wolfgang Goethe-University, Frankfurt am Main, Germany \\ ${ }^{3}$ Institute of Geological Sciences, Bern, Switzerland
}

Many primitive magmas may derive from partial melting of complex, mixed mantle lithologies including recycled crust and peridotite. However, there is little detailed knowledge of how such material melts, the sorts of liquids produced and how they are extracted from the mantle.

We are searching for evidence of heterogeneous melting, melt migration and refertilisation in natural mantle samples, particularly investigating the nature of reactions between high pressure partial melts of mafic layers or bodies in the upper mantle (eclogites, garnetclinopyroxenites) and surrounding peridotite. Some orogenic peridotite massifs with veined pyroxeniteperidotite assemblages may provide an excellent opportunity to understand processes of heterogeneous mantle melting.

\section{The Western Gneiss Region (WGR)}

Such an opportunity may be represented by some of the peridotite and pyroxenite massifs of the WGR (Fig. 1).

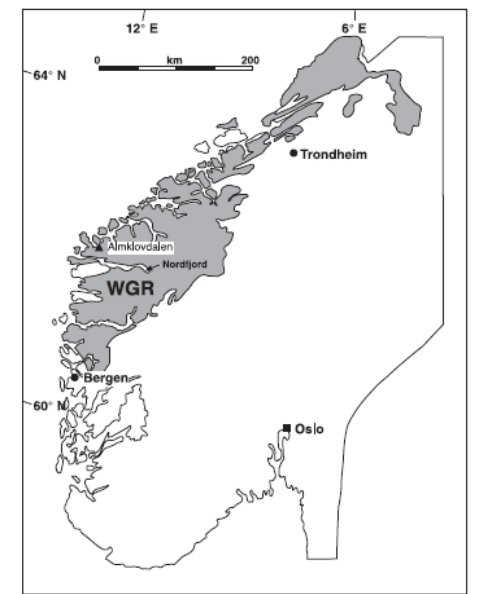

Fig. 1 Map of WGR (from Beyer et al., 2006).

The WGR, part of the Scandinavian Caledonianes, represents a giant tectonic window of the Baltica Proterozoic basement beneath a sequence of late Silurian-early Devonian thrust nappes (Terry et al., 2000; Beyer et al., 2006).
At numerous scattered localities in the WGR, Proterozoic gneisses surround lensoid masses of orogenic peridotites, often comprising large bodies of garnet-free, chromite-bearing dunites in association with discrete zones of garnet peridotites interlayered with a broad range of pyroxenites (e.g. Brueckner et al., 2002; Beyer et al., 2006). These high-pressure and ultrahigh-pressure peridotite bodies represent fragments of ancient subcontinental mantle, probably emplaced into the crustal rocks during the Late Silurian (Caledonian) continental collision of Laurentia with Baltica (e.g. Brueckner \& Medaris, 2000; Brueckner et al., 2002). Even though the mantle-derived peridotite bodies of the WGR suffered complex tectonothermal histories over a long time, including different metamorphic stages (subduction, exhumation, extension, pervasive deformation, retrogression, and fluid infiltration) (e.g. Carswell \& van Roermund, 2003), they are thought to represent still intact mantle sections (Beyer et al., 2006).

\section{The Almklovdalen peridotite body}

The Almklovdalen high-pressure peridotite body in the WGR of Norway (Fig. 2) is remarkably well-preserved peridotite-pyroxenite body.

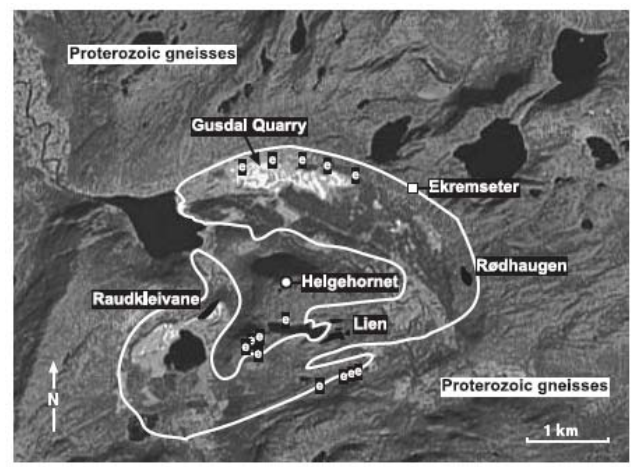

Fig. 2 Map of Almklovdalen peridotite body (from Beyer et al., 2006).

Chlorite-poor dunite or harzburgite dominate the massif, which is being extensively mined for olivine (Beyer et al., 2006). The Rødhaugen and Lien 
localities, which lie within the Almklovdalen body, and on which we concentrated our fieldwork, are known for their chlorite-rich peridotites enclosed by the massive dunite bodies. These chlorite-rich peridotites show evidence of retrograde metamorphism of garnet to chlorite along the margins of the peridotite body (e.g. Medaris, 1984), and contain as interlayers from $\mathrm{cm}$ to $\mathrm{m}$ scale garnet lherzolite, a wide range of garnet-free to garnet-bearing clinopyroxenites, wehrlites, websterites, and eclogites (Beyer et al., 2006; this study). These layers are often isoclinally folded.

We have sampled a range of different lithologies present within the Almklovdalen peridotite body. We aim to determine their petrographical and geochemical relationships, and to determine compositional changes either along individual peridotitic/pyroxenitic layers or between them. We sampled transversely from one layer to the other, across their contacts towards the next layer.

\section{Rødhaugen}

Studies in Rødhaugen are based (a) on a roughly $3.0 \mathrm{x}$ $5.0 \mathrm{~m}$ boulder found next to an in-situ outcrop at Rødhaugen (Fig. 3), and (b) on an outcrop within a waterfall $\sim 1 \mathrm{~km}$ from the Rødhaugen outcrop, called 'Rødhaugen waterfall outcrop' (Fig. 4).

The Rødhaugen bolder comprises mainly layers of numerous varieties of (olivine-and orthopyroxenebearing) garnet clinopyroxenites and (chlorite-bearing) dunite, which represent according to Carswell (1981) widely varying garnetiferous peridotite at different stages of retrograde metamorphism.

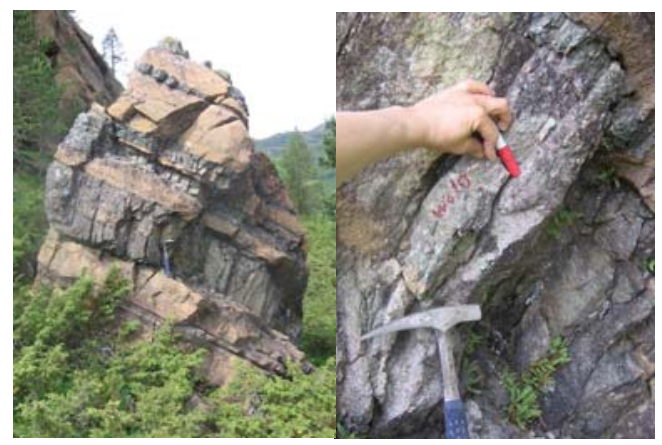

Fig. 3 (left): The classic Rødhaugen locality, an isolated knob. The metre-thick layer of an olivinebearing garnet clinopyroxenite with dunite patches (hammer therein, used as scale), known as the 'Rødhaug type eclogite' of Eskola (1921). (right): Careful sampling of this layer from the centre (garnet clinopyroxenite) to the edge of the layer (clinopyroxenite with \pm garnet) towards the adjacent small layer of dunite.

The 'Rødhaugen waterfall outcrop' comprises a $\sim 1.5 \mathrm{~m}$ broad layer of eclogite enclosed within a strongly serpentinsied dunite body (Fig. 4).

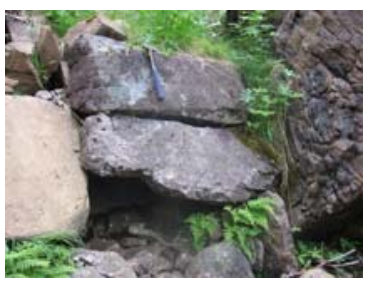

Fig. 4 The 'Rødhaugen waterfall outcrop': an eclogitic layer surrounded by the prevailing rock type of Almklovdalen, dunite.

\section{Lien}

The typical Almklovdalen peridotite body (Fig. 5) consists of complexly folded and foliated refractory peridotite with concordant layers of:

1. massive garnet clinopyroxenite ( $\leq 1.5 \mathrm{~m}$ across), and

2. thinner layers within the surrounding peridotite which exhibit strong enrichment in modal garnet and/or clinopyroxene and/or orthopyroxene.

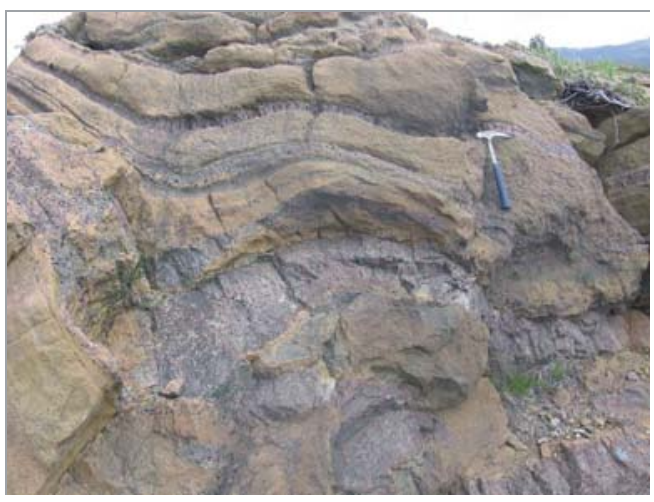

Fig. 5 Outcrop of peridotite at Almklovdalen peridotite body, WGR. It contains two discernible adjacent distinctive folded eclogite layers.

\section{Preliminary results}

Preliminary work indicates the following:

1. Peridotite layers underwent metamorphism at increasing pressure, evident in spinel inclusions within garnet porphyroclasts.

2. Both, peridotite and pyroxenite layers are strongly overprinted by retrograde cooling processes.

3. Garnet pyroxenite layers exhibit higher modal opx/cpx ratios in the centre compared with the margins (Fig. $6 \& 7$ ).

4. The clinopyroxene and garnet in the eclogite from the 'Rødhaugen waterfall outcrop' are much higher in jadeite component, but possess much lower $\mathrm{Mg \#}$ and less $\mathrm{Cr}_{2} \mathrm{O}_{3}$ than those in the garnet pyroxenite layers of the peridotite bodies.

5. The massive garnet clinopyroxenite layers are refractory, having lost a melt fraction. This partial melt fraction (inferred on the basis of high pressure experimental data) is expected to have been siliceous and should have reacted with the peridotite wall rock when it segregated from its source. The evidence for this is as follows: 
a. Clinopyroxene grains in the refractory garnet clinopyroxenite layers are lower in jadeite component, lower in $\mathrm{Cr}_{2} \mathrm{O}_{3}$ content, but higher in $\mathrm{Mg} \#$ compared with those in the peridotite adjacent to the layer (Fig. 6), consistent with partial melting of earlier more fertile garnet clinopyroxenite.

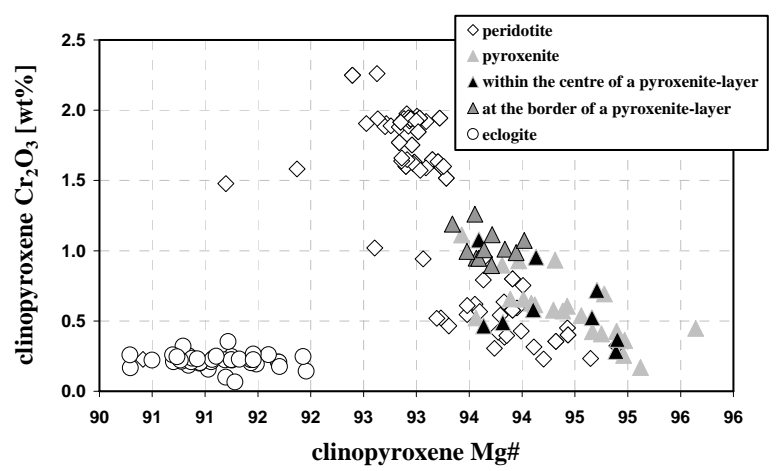

Fig. $6 \mathrm{Mg \#}$ vs. $\mathrm{Cr}_{2} \mathrm{O}_{3}$ of clinopyroxene in peridotite and garnet clinopyroxenite layers.

b. Garnet grains in the refractory garnet

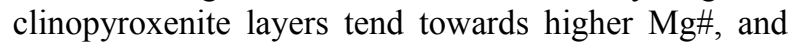
are lower in $\mathrm{Cr}_{2} \mathrm{O}_{3}$ than those in the peridotite adjacent to the layer (Fig. 7).

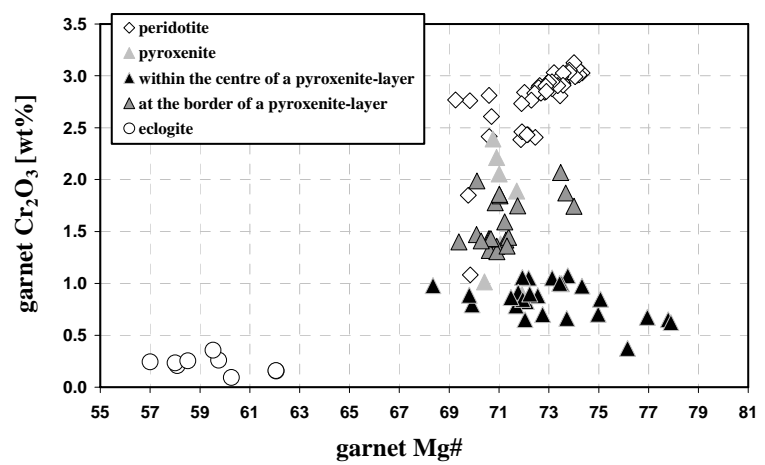

Fig. $7 \mathrm{Mg \#}$ vs. $\mathrm{Cr}_{2} \mathrm{O}_{3}$ of garnet in peridotite and garnet clinopyroxenite layers.

c. Contacts between the clinopyroxenite and peridotite are sometimes decorated by thin orthopyroxene-rich layers, consistent with reaction between the siliceous partial melts of the garnet clinopyroxenite (?formerly eclogite sensu stricto) and peridotite wall rock, in the manner described by Yaxley \& Green (1998).

Also, field observations suggest more granoblastic textures in garnet pyroxenites and olivine-bearing garnet pyroxenites, contrasting with peridotitic layers and particularly dunite, which exhibit strong grain orientation. If melting occurred in some compositions while other more refractory compositions remained subsolidus, then a trend towards rheological homogeneity during deformation (i.e. thin parallel layers) may be achieved by grain size reduction (strong crystallographic alignment) in olivine-rich refractory compositions and coarser, granoblastic textures where flow is facilitated by interstitial melt.

By combining detailed petrographic and mineral and whole rock chemical investigations of these samples, it is hoped to develop an understanding of the geological history of this body and to relate this to development of the layers and partial melting of heterogeneous mantle. Measurements of $\mathrm{Fe}^{3+} / \sum \mathrm{Fe}$ in garnets from Norwegian peridotites and garnet-clinopyroxenites using the electron microprobe "flank method" (Hoefer \& Brey, 2007) and Mossbauer spectroscopy, respectively, at University Frankfurt are also currently being undertaken to establish the oxidation state of the Norwegian peridotite body, and also to develop standards for $\mathrm{Fe}^{3+} / \sum \mathrm{Fe}$ in garnets.

\section{References}

Beyer, E.E., Griffin, W.L., O'Reilly, S.Y., 2006. Transformation of Archaean lithospheric mantle by refertilization: Evidence from exposed peridotites in the Western Gneiss Region, Norway. Journal of Petrology, 47, 8, 1611-1636.

Brueckner, H.K., Medaris, L.G., 2000. A general model for the intrusion and evolution of 'mantle' garnet peridotites in high-pressure and ultra-highpressure metamorphic terranes. Journal of Metamorphic Geology 18, 2, 123-133.

Brueckner, H.K., Carswell, D.A., Griffin, W.L. 2002. Paleozoic diamonds within a Precambrian peridotite lens in UHP gneisses of the Norwegian Caledonides. Earth and Planetary Science Letters 203, 3-4, 805-816.

Carswell, D.A., 1981. Clarification of the petrology and occurrence of garnet lherzolites, garnet websterites and eclogite in the vicinity of Rødhaugen, Almklovdalen, West Norway. Norsk Geologisk Tidsskrift 61, 249-260.

Carswell, D.A., van Roermund, H.L.M., 2003. The occurrence and interpretation of garnet peridotite bodies in the Western Gneiss Region. In: Carswell, D.A. (ed.) Guidebook to the Post-Selje Eclogite Field Symposium Field Excursion. Trondheim: Norges Geologiske Undersøkelse.

Eskola, P., 1921. On the eclogites of Norway. Skrifter Utgitt av det Norske Videnskaps-selsk. Christiana, Matematisk-Naturvidenskapelig Klasse 18, 1-118.

Hoefer, H.E., Brey, G.P., 2007. The iron oxidation state of garnet by electron microprobe: Its determination with the flank method combined with major-element analysis. American Mineralogist 92, 5-6, 873-885.

Medaris, L.G., 1984. A geothermobarometric investigation of garnet peridotites in the Western Gneiss Region of Norway. Contributions to Mineralogy and Petrology 87, 72-86.

Terry, M.P., Robinson, P., Ravna, E.J.K., 2000. Kyanite eclogite thermobarometry and evidence for thrusting of UHP over HP metamorphic rocks, Nordoyane, Western Gneiss Region, Norway American Mineralogist, 85, 1637-1650.

Yaxley, G.M., Green, D.H., 1998. Reactions between eclogite and peridotite: mantle refertilisation by subduction of oceanic crust Schweizerische Mineralogische und Petrographische Mitteilungen 78, 2, 243-255. 